\title{
Didactical Design of Mathematical Reasoning in Mathematical Basic Concepts of Courses
}

\author{
Lilis Marina Angraini \\ Pendidikan Matematika, Universitas Islam Riau, Pekanbaru, Indonesia; \\ lilismarina@edu.uir.ac.id
}

Info Artikel: Dikirim: 27 Juli 2020; Direvisi: 21 September 2020; Diterima: 1 Maret 2021 Cara sitasi: Angraini, L. M. (2021). Didactical Design Of Mathematical Reasoning In Mathematical Basic Concepts Of Courses 5(1), 1-12.

\begin{abstract}
Abstrak. Penelitian ini dilatarbelakangi oleh kesulitan epistemologis siswa dalam konsep matematika. Penelitian ini bertujuan untuk membuat desain didaktis pada mata kuliah Konsep Dasar Matematika. Metode yang digunakan adalah Didactic Design Research (DDR). Penelitian ini dilakukan di Universitas jurusan Pendidikan Guru Sekolah Dasar semester pertama di Riau yang mengikuti mata kuliah Konsep Dasar Matematika sebanyak 43 siswa. Teknik pengumpulan data dalam penelitian ini dilakukan dengan triangulasi yang merupakan gabungan dari tes tertulis, wawancara dan studi dokumentasi, dengan sumber data mahasiswa dan dosen. Hasil penelitian berupa desain didaktis yang terdiri dari tiga desain pembelajaran. Pertama menyusun desain didaktis awal berdasarkan kesulitan siswa, kedua analisis notasi metapedadidaktik dilakukan selama pembelajaran berlangsung dan ketiga analisis retrospektif dilakukan dengan membandingkan hasil tes pembelajaran hambatan awal dengan hasil tes pembelajaran hambatan akhir. Analisis retrospektif yang dilakukan dengan membandingkan hasil tes pembelajaran hambatan awal dan hasil tes pembelajaran hambatan akhir. Hasil menunjukkan bahwa kesulitan belajar siswa semakin sedikit dan beberapa masih terjadi, sehingga diperlukan revisi desain didaktis untuk memperbaiki desain didaktis awal agar kesulitan belajar siswa dapat teratasi. Hasil implementasi desain didaktis konsep penalaran matematis siswa sesuai dengan prediksi tanggapan yang dibuat.
\end{abstract}

Kata Kunci: Desain Didaktis, Penalaran Matematika, Hambatan Belajar, Analisis Retrospektif.

\begin{abstract}
This research is motivated by the epistemological difficulties of students in mathematical concepts. This research aims to make a didactic design in courses of Mathematics Basic Concepts. The method used in this research is Didactic Design Research (DDR). This research was conducted at the University majoring in Elementary School Teacher Education in the first semester in Riau, who attended in courses of Mathematics Basic Concepts as many as 43 students. Data collection techniques in this research were carried out by triangulation which is a combination of written tests, interviews and documentation studies, with data sources of students and lecturers. The results of the study were didactic designs consisting of three learning designs. Didactic design was developed through three stages. Firstly arranging an initial didactic design based on student difficulties, secondly a methapedadidactic analysis is carried out while learning takes place and thirdly a retrospective analysis is done by comparing the results of the initial obstacle learning test and the results of the final obstacle learning test. The retrospective analysis carried out by comparing the results of the initial obstacle learning test and the results of the final obstacle learning test. Result shows that there are fewer student learning difficulties and some are still happening, so that a revised didactic design is needed to improve
\end{abstract}


the initial didactic design so that student learning difficulties can be overcome. The results of the didactic design implementation of students' mathematical reasoning concepts are in accordance with the predictions of the responses made.

Keywords: Didactic Design, Mathematical Reasoning, Learning Obstacle, Retrospective Analysis.

\section{Introduction}

Didactic Design is a learning design in the form of teaching material that is developed based on the research study identification of obstacles in the mathematics learning process that has emerged previously. During the learning process in the classroom, didactical design teaching materials are made through a series of didactic situations along with predictions of their responses and anticipations. Didactic design is designed with the aim to overcome or reduce the learning obstacle that appears in previous learning, so students are able to understand the concept of a material in mathematics as a whole. By using a didactic design it is expected that learning obstacles experienced by students can be reduced so that the objectives of learning mathematics can be achieved properly (Suryadi, 2016). According to Nurwani, Putra, Putra, \& Putra (2017) the development of didactic design has a role in learning mathematics and learning mathematics. The role is very influential on how they do learning in the classroom (Suryadi, 2013). Even the development of new theories is expected to be able to answer the obstacles of learning, learning trajectory and student characteristics. The development of didactic designs needs to be continued both by teachers and researchers (Ernasari, 2016).

According to Creswell (2014), there are two basic aspects in mathematics learning, namely the relationship between students and material and the relationship between students and teachers. The relationship between teacher and student is called pedagogical relation, while the relationship between students and material is called didactical relation, which is usually presented in a didactic triangle. Creswell (2014) further states that the teacher's relationship with the material cannot be ignored. According to Suryadi (2016) Didactical Relation and Pedagogical Relation, cannot be viewed partially but can occur simultaneously. In this case, the teacher can design a didactic situation and make predictions of student responses and their anticipation to create a new situation. Thus, in the didactic triangle, an anticipatory relationship between teacher and student needs to be added, which is called Pedagogical Didactic Anticipation.

In the didactic triangle the teacher's role is to create a didactic situation (didactical situation) so that the learning process occurs within students. This indicates that the teacher must really master the teaching material, knowledge 
about students, and create a didactic situation to optimize learning. This is then known as didactic relations (Suryadi, 2011). Didactic and pedagogical situations are very complex, so the teacher must have the ability to look at it comprehensively, be able to identify and analyze important things that happen, and take appropriate actions for optimal learning. This ability is hereinafter referred to as methapedadidactic (Suryana,Pranata, \& Apriani, 2012; Romdhani \& Suryadi, 2016).

Methapedadidactic consists of three important components, namely unity, flexibility, and logical coherence. Unity means that the teacher is able to see the sides of the modified didactic triangle as whole. Flexibility is the anticipation that has been prepared by the teacher in accordance with didactic and pedagogical. Coherence means didactic situations that develop in each milieu until different situations arise, then differences in the situation must be managed so that changes in the situation during the learning process run smoothly and lead to the achievement of objectives (Suryadi, 2013; Robbia, 2013). In didactical design research (DDR), so that the development of didactic situations, analysis of learning situations, and decision making during the learning process can lead to optimal learning situations that require maximum effort that must be done before learning. This effort, known as Pedagogical Didactic Anticipation, is a synthesis of the results of thinking based on the possibilities that are predicted to occur in the learning process (Suryadi, 2011).

The aspect that must be considered in developing Pedagogical Didactic Anticipation is the existence of learning difficulties (learning obstacle), moreover that is epistemological (epistemological obstacle). Rohimah (2017) argues that learning difficulties are a symptom that appears in students marked by low learning outcomes compared to previous achievements. So, learning difficulties is a condition in the learning process that is marked by the presence of certain obstacles in achieving learning outcomes.

Learning difficulties here are learning difficulties commonly known as learning obstacles. There are 3 types of learning obstacle, namely ontogenical learning obstacle, didactical learning obstacle and epistemological learning obstacle (Yusuf, Titat, \& Yuliawati, 2017; Safi'i, 2013). Ontogenical learning obstacle is psychological based learning difficulties, where students have learning difficulties due to mental readiness, in this case students' way of thinking is not included due to age. Didactical learning obstacle is the difficulty of student learning due to misrepresentation, in this case teaching materials used by students in learning can lead to misconceptions. Epistemological learning obstacle is the difficulty of student learning because 
students' understanding of a concept is incomplete, only seen from its origins. Learning difficulties experienced by students also occur in Elementary School Teacher Education students, especially in terms of mathematical reasoning ability (Marsetyorini \& Murwaningtyas, 2012; Adiwinata, Masykur, \& Putra, $\underline{2018})$.

The ability of mathematical reasoning is the ability to express arguments that are essential for understanding mathematics (Kahan, 2013). Mathematical reasoning is a process that always takes place in the mind that must be developed consistently using a variety of contexts. This means that mathematical reasoning is the ability to analyze mathematical situations that take place, then the results of the analyzing process reach a concrete conclusion. Reasoning is a thought process that connects known facts to a conclusion (Loc \& Uyen, 2014). This is in line with what was revealed by Mofidi, Amiripour, \& Zadeh (2012), who stated reasoning as the process of drawing logical conclusions based on facts and sources. Based on the two opinions above it can be concluded that the ability of reasoning is needed to obtain a conclusion based on the facts that exist before making a decision.

Several studies on the importance of mathematical reasoning abilities have been conducted by Jonas (2016), Elvis, Suryadi, \& Kusumah (2016), Elvis (2017) and Mik\& Nisa (2018). These studies state that mathematical reasoning skills need to be possessed by students so that students' thinking abilities become better. To have good mathematical reasoning skills, a learning design is needed that can improve students' mathematical reasoning abilities. The learning design is of course designed based on didactic aspects, so that the design is designed according to the anticipation of possible responses that will arise.

Priestley (2013) revealed that mathematics is a knowledge gained through reasoning, mathematics is knowledge about logical reasoning and knowledge of logical structures. Trouche, Johansson, Hall, \& Mercierd (2015) assert that assessment of good mathematical reasoning is an assessment that pays attention to aspects of mathematical reasoning, including metacognitive activities that are seen when (1) asking students to formulate strategies to solve problems; (2) asking students to monitor and evaluate completion. The purpose of this study is to conduct a retrospective analysis by comparing the results of the initial obstacle learning test and the results of the final obstacle learning test. 


\section{Method}

This research was conducted at the University majoring in Primary School Teacher Education in the first semester in Riau, following the Mathematics Basic Concept courses in the 2019/2020 school year as many as 43 students. Determination of the location of research based on characteristics that have been determined by researchers. While the determination of the class chosen as a research subject is based on the considerations of the lecturer at the research site. The method used in this study is Didactical Design Research (DDR). DDR thinks comprehensively about what is presented, how the students' possible responses are, and how to anticipate them. This thinking process is carried out in 3 (three) phases of learning, namely before learning, during learning, and after learning. The teacher's thought process in these three phases along with the results of their analysis has the potential to produce innovative didactic designs (Suryadi, 2013).

This didactic design research consists of three stages, namely: (1) didactic situation analysis before learning whose form is a hypothetical didactic design including Pedagogical Didactic Anticipation, (2) methapedadidactic analysis, and (3) retrosfective analysis which is an analysis linking the results of a didactic situation analysis with hypotheses the results of the methapedadidactic analysis (Suryadi 2011). From these three stages an empirical didactic design will be obtained which is likely to continue to be refined through the three DDR stages.

The instruments in this study consisted of mathematical reasoning test instruments, didactic designs of mathematical reasoning, questionnaires, and observation sheets. The mathematical reasoning test instrument in the Mathematical Basic Concepts Courses, is the same instrument used at the time of the preliminary study which has passed the stages of validity, reliability, differentiation, and difficulty level. Didactic design of mathematical reasoning in Mathematical Basic Concepts Courses, used during didactic design trials or implementations. The questionnaire instrument contained student responses related to the use of didactic designs during learning. Observation sheets are used to observe the activities of lecturers and students while learning during a didactic design trial. Data collection techniques in this research were carried out by triangulation which is a combination of written tests, interviews and documentation studies, with data sources of students and lecturers. 


\section{Results and Discussion}

The preparation of teaching materials is generally based on competency standards and basic competencies of related subjects. Teaching material to be delivered must also be in accordance with established standards. At the stage of repersonalization, the researcher analyzes the students' mathematics teaching material, the researcher examines the context and concept of the material to be studied. Before preparing teaching materials, a lecturer needs to understand the context of any material and the concept of learning material that will be taught later.

Furthermore, at the stage of re-conceptualization the researcher collects and analyzes the student's conception of the teaching material to be examined through the results of the learning obstacle test and the results of the lecturer and student interviews. The type of learning obstacle that will be investigated is epistemological obstacle (mathematical reasoning ability) of students' mathematical reasoning ability in the mathematical basic concept courses. Epistemological barriers are a person's knowledge which is only limited to certain contexts because students experience a leap of information on prior knowledge.

Based on the results of interviews and questionnaires about mathematical learning difficulties given to students, the following conclusions are obtained: (1) students generally find it difficult to learn mathematics because mathematics has too many formulas; (2) the difficulty of mathematics materials causes students to consider mathematics learning boring so they tend to ignore the teacher's explanation related to the mathematical material being explained; (3) the difficulties they experienced in learning mathematics material led them to conclude that the use of mathematics in daily life was also not very often found; (4) mathematical tasks are too numerous and tend to be more difficult than the sample problems explained; (5) students stated that they often felt dizzy working on math problems, especially questions in the form of stories.

This didactic design was prepared based on the results of analysis of student learning difficulties, namely the identification of obstacles and errors that arise when students solve mathematical problems or during previous learning. This didactic design consists of several activities with different materials with the aim of strengthening the concept of student learning materials. 


\section{Retrospective Analysis}

At this stage the researcher tests the final learning obstacle instrument to determine the effectiveness of the didactic designs that have been implemented. The instrument used for testing this final learning obstacle is the same as the questions used in the initial obstacle learning test. The two test results of the instrument will be compared to measure the effectiveness of the didactic design implementation. Didactic design is said to be effective if the design is able to reduce the difficulties experienced by students in learning mathematical concepts. The following will discuss the results of the student's final obstacle learning test.

A mother distributes sweets to 5 children according to the rules of the series arithmetic. The younger the age of the child lots of candy obtained. If many sweets received by the second child 11 pieces and the fourth child 19 pieces, then the number all sweets are ... fruit. Based on the illustration of the problem above,

a. Make what is known and asked.

b. Discover the pattern or nature of the symptoms mathematically to make generalizations!

Figure 1. Instrument Number 1

The first obstacle learning instrument regarding an everyday life problem about arithmetic progression, which has rows $a, b$, and so on. The indicator is students can determine the number of arithmetic sequences. In question number (1) students are asked to answer 4 question items, namely: 1) make what is known and asked based on the questions; (2) finding patterns or properties of mathematical symptoms to make generalizations; (3) determine mathematical manipulation to solve problems; (4) make logical conclusions from the problem. The percentage of initial obstacle learning testing is $0 \%$, while the percentage of final obstacle learning testing is 100\%. All students can answer item question questions number (1) well. This means that didactic design has been very effective in reducing the difficulties experienced by students in learning mathematical concepts. Next is the discussion of the second obstacle learning instrument.

A rope is divided into 6 sections with length measures form a geometrical sequence, if the shortest part is $3 \mathrm{~cm}$ and the longest $96 \mathrm{~cm}$, determine the size the length of the rope. Based on the illustration of the problem above,

a. Make what is known and asked!

b. Discover the pattern or nature of the symptoms mathematically to make generalizations!

c. Determine the mathematical manipulation of the problem above!

Figure 2. Instrument Number 2 
The second obstacle learning instrument regarding a problem of daily life about geometrical progression, which has rows $\mathrm{a}, \mathrm{b}$ and so on. The indicator students can determine the number of geometric lines. In question number (2) students are asked to answer 4 question items, namely: 1) make what is known and asked based on the questions; (2) finding patterns or properties of mathematical symptoms to make generalizations; (3) determine mathematical manipulation to solve problems; (4) make logical conclusions from the problem. The percentage of initial obstacle learning testing is $0 \%$, while the percentage of final obstacle learning testing is $100 \%$. All students can answer item question number (2) well. This means that didactic design has been very effective in reducing the difficulties experienced by students in learning mathematical concepts. Next is the discussion of the third obstacle learning instrument.

The number of populations the city of Bandung in 2007 there were 3.2 million people. Every 10 year populations the city of Bandung doubled from the original number. How much the number of populations the city of Bandung in 1947?. Based on the illustration of the problem above,

a. Make what is known and asked!

b. Discover the pattern or nature of the symptoms mathematically to make generalizations!

Figure 3. Instrument Number 3

The third obstacle learning instrument concerning a problem of daily life is about geometric sequences, which have sequences $a, b$ and so on. The indicator is students can determine the nth value of the geometric sequence. In question number (3) students are asked to answer 4 question items, namely: 1) make what is known and asked based on the questions; (2) finding patterns or properties of mathematical symptoms to make generalizations; (3) determine mathematical manipulation to solve problems; (4) make logical conclusions from the problem. The percentage of initial obstacle learning testing is $0 \%$, while the percentage of final obstacle learning testing is $19.1 \%$. The percentage of students who could not answer the third obstacle learning instrument was $80.9 \%$, meaning that didactic design was not effective enough to reduce the difficulties experienced by students in learning mathematical concepts. However, based on the results of the interviews, students found it difficult to work on the third obstacle learning instrument because the numbers on the problem were too large, causing confusion for them. Next is the discussion of the fourth obstacle learning instrument. 
An employee gets a starting salary Rp. 1,600,000.00 a month. If every year he got a salary increase of Rp. 100,000.00. Look for the amount of income received the employee within 10 years. Based on the illustration of the problem above,

a. Make what is known and asked!

b. Discover the pattern or nature of the symptoms mathematically to make generalizations!

Figure 4. Instrument Number 4

The fourth obstacle learning instrument regarding an everyday life problem about arithmetic progression, which has rows $a, b$ and so on. The indicator is students can determine the number of arithmetic sequences. In question number (4) students are asked to answer 4 question items, namely: 1) make what is known and asked based on the questions; (2) finding patterns or properties of mathematical symptoms to make generalizations; (3) determine mathematical manipulation to solve problems; (4) make logical conclusions from the problem. The percentage of initial obstacle learning testing is $0 \%$, while the percentage of final obstacle learning testing is $83.4 \%$. The percentage of students who could not answer the third obstacle learning instrument was $16.6 \%$, meaning that didactic design was effective in reducing the difficulties experienced by students in learning mathematical concepts. Next is the discussion of the fifth obstacle learning instrument:

A ball is dropped from a height of 1 meters. Every time after falling regarding the floor, the ball is reflected back and reaches $3 / 4$ height from the previous height. Determine it the length of the entire path the ball traveled until it stops. Based on the illustration of the problem above,

a. Make what is known and asked!

b. Discover the pattern or nature of the symptoms mathematically to make generalizations!

Figure 5. Instrument Number 5

The fifth obstacle learning instrument concerning a problem of daily life about geometrical progression, which has rows $\mathrm{a}, \mathrm{b}$ and so on. The indicator students can determine the number of geometric lines. In question number (5) students are asked to answer 4 question items, namely: 1) make what is known and asked based on the questions; (2) finding patterns or properties of mathematical symptoms to make generalizations; (3) determine mathematical manipulation to solve problems; (4) make logical conclusions from the problem. The percentage of initial obstacle learning testing is $0 \%$, while the percentage of final obstacle learning testing is $71.5 \%$. The percentage of students who cannot answer the third obstacle learning instrument is $28.5 \%$, 
meaning that didactic design has been effective to reduce the difficulties experienced by students in learning mathematical concepts.

Based on the overall results on each item, it was seen that the decrease in the percentage of students who experienced difficulties when completing the obstacle learning test questions after implementing the didactic design was good, except for the codification of item number 3 which did not go down too large. There are many decreases in the number of students who have difficulty in several items, especially items $1 \& 2$, but there are also many students who cannot complete item 3, so it is the researcher's task to further analyze learning barriers and students' difficulties in solving mathematical problems, especially in items question 3 is. If further observed, the decrease in the number of students who experience difficulties is not too large in the material and geometric sequence, this can be seen from the results of students' completion of the geometrical sequence and series, represented by learning instrument obstacles number 3 and 5. Thus Didactic designs of geometric sequences and series that have been compiled are categorized as low effective. This didactic design needs to be developed continuously through further research so that it can overcome and reduce the difficulties of larger students. While the didactic design of arithmetic numbers, sequences and arithmetic sequences that have been compiled is categorized as effective because there has been a decrease in the number of students who have difficulty with material and arithmetic sequences.

Based on the results of the study, there are several obstacles experienced by students in mathematical reasoning abilities, namely: obstacles regarding the concept of the material being studied, obstacles regarding the relationship concepts between materials, obstacles regarding too many concepts in the material being studied and obstacles regarding recognizing the types of questions that represent each ofconcept. With the discovery of these obstacles, it is necessary to design learning from each material studied, the learning design that is formed is not only viewed from a didactic aspect but can also be viewed from other aspects such as pedagogical aspects.This is in line with the didactical design research theory that by using a didactic design it is expected that learning obstacles experienced by students can be reduced so that the objectives of learning mathematics can be achieved properly (Suryadi, 2016). The development of didactic design has a role in learning mathematics, the role is very influential on how they do learning in the classroom (Suryadi, 2013). Suryadi (2016) Didactical Relation and Pedagogical Relation, cannot be viewed partially but can occur simultaneously. In this case, the teacher can design a didactic situation and make predictions of student responses and 
their anticipation to create a new situation. Thus, in the didactic triangle, an anticipatory relationship between teacher and student needs to be added, which is called Pedagogical Didactic Anticipation.

\section{Conclusion}

Based on the analysis of the results of the study and the discussion, the following conclusions can be drawn: learning obstacle that is identified related to students' mathematical reasoning abilities in the basic mathematical concept courses are: (a) learning obstacle related to the concept of number patterns, sequences and arithmetic sequences, and sequences and geometry series; (b) obstacle learning is related to solving students' mathematical reasoning ability questions; (c) obstacle learning is related to other mathematical material concepts.

The didactic design developed was in the form of a learning design completed with Student Worksheets which was compiled based on the results of identification of student difficulties during the initial obstacle learning test and relevant learning theory. The results of the didactic design implementation of students' mathematical reasoning concepts are in accordance with the predictions of the responses made, while the unpredictable student responses are anticipated with solutions taken while learning takes place.

The epistemological learning obstacles identified in this study include the following: (a) Difficulties of students in learning mathematics because mathematics is too much formula; (b) Difficulties related to the connection of the concept of number patterns, arithmetic sequences and sequences, and geometric sequences and sequences; (c) Difficulty in understanding story problems; (d) Difficulties in analyzing differences in numbers, arithmetic sequences and sequences, and geometric sequences and rows; (e) Difficulties related to the connection of material concepts with other mathematical concepts.

\section{References}

Adiwinata, R., Masykur, R., \& Putra, R. W. Y. (2018). Learning obstacle untuk siswa SMP materi tabung dan kerucut. Prosiding Seminar Nasional Matematika dan Pendidikan Matematika. UIN Raden Intan Lampung.

Creswell, W. J. (2014). Research desain (pendekatan kualitatif, kuantitatif, dan mix). Jogyakarta: Pustaka Pelajar.

Elvis, N., Suryadi, D., \& Kusumah, Y. S. (2016). Cultivating upper secondary students' mathematical reasoning ability and attitude towards mathematics through problembased learning. Journal on mathematics education 7(2), 61-71. DOI: https://doi.org/10.22342/jme.7.2.3542.117-128 
Elvis, N. (2017). Analyzing the teaching and learning of mathematical reasoning skills in secondary school. Asian social science 13(12), 167-173. DOI: 10.5539/ass.v13n12p167

Ernasari, T. (2016). Desain didaktis materi jenis dan besar sudut berdasarkan analisis learning obstacle pada buku paket teks matematika kelas III sekolah dasar di kota serang. Kalimaya 4(2), 1-16.

Jonas, J. (2016). Students' mathematical reasoning and beliefs in non-routine task solving. International Journal of Science and Mathematics Education 15(4), 759-776. DOI: $10.1007 /$ s10763-016-9712-3

Kahan, D.M. (2013). Ideology, motivated reasoning, and cognitive reflection. Judgment and Decision Making 8(4), 407-424.

Loc \& Uyen. (2014). Using analogy in teaching mathematics: an investigation of mathematics education students in school of education. International Journal of Education and Research 2(7), 91-98.

Mofidi, S., Amiripour, P. \& Zadeh, M. (2012). Instruction of mathematical concepts through analogical reasoning skills. Indian Journal of Science and Technology 5(6), 1-7.

Marsetyorini, A. D. \& Murwaningtyas. (2012). Diagnosis kesulitan belajar siswa dan pembelajaran remedial dalam materi operasi pada pecahan bentuk aljabar di kelas viii smpn 2 jetis bantul. Prosiding Seminar Nasional Matematika dan Pendidikan Matematika. FMIPA UNY Yogyakarta.

Mik, S. \& Nisa, S. K. (2018). Kemampuan penalaran matematis siswa berdasarkan gender pada materi geometri. Jurnal Numeracy 5(1), $41-48$.

Nurwani, Putra, R. W. Y., Putra, F. G., \& Putra, N. W. (2017). Pengembangan desain didaktis bahan ajar materi pemfaktoran bentuk aljabar pada pembelajaran matematika SMP. Numerical: Jurnal Matematika dan Pendidikan Matematika 1(2), 193-206.

Priestley, M. (2013). Wandering about: analogy, ambiguity and humanistic mathematics. Journal of Humanistic Mathematics 3(1), 1-22.

Robbia, D. (2013). Desain didaktis model problem solving untuk mengatasi learning obstacle pokok bahasan teorema phytagoras pada pembelajaran matematika untuk meningkatkan kompetensi matematis SMP. Disertasi. UPI Bandung.

Rohimah, S. M. (2017). Analisis learning obstacles pada materi persamaan dan pertidaksamaan linier satu variabel. JPPM 10(1), 132-141.

Romdhani, W. \& Suryadi, D. (2016). Desain didaktis konsep pecahan untuk kelas iii sekolah dasar. Edu Humaniora: Jurnal Pendidikan Dasar 8(2), 198-210.

Suryadi, D. (2011). Didactical design research (ddr) dalam pengembangan pembelajaran matematika 1. Jurnal Ilmu Pendidikan 1(1), 1-10.

Suryadi, D. (2013). Didactical design research (DDR) dalam pengembangan pembelajaran matematika. Prosiding Seminar Nasional Matematika dan Pendidikan Matematika. UPI.

Suryadi, D. (2016). Didactical design research (ddr): upaya membangun kemandirian berpikir melalui penelitian pembelajaran. Seminar Nasional Matematika dan Pendidikan Matematika. Unswagati.

Suryana, Y., Pranata, O. H., \& Apriani, I. F. (2012). Desain didaktis pengenalan konsep pecahan sederhana pada pembelajaran matematika untuk siswa kelas iii sekolah dasar. Jurnal ilmu pendidikan 1(2), 1-10.

Safi'i, I. (2013). Diagnosis kesalahan siswa pada faktorisasi bentuk aljabar dan scaffoldingnya. Jurnal Ilmu Pendidikan 1(3), 1-10.

Trouche, E., Johansson, P., Hall, L., \& Mercierd, H. (2015). The selective laziness of reasoning. Cognitive Sciencee 40(2016), 2122-2136.

Yusuf, Y., Titat, N., \& Yuliawati, T. (2017). Analisis hambatan belajar (learning obstacle) siswa SMP pada materi statistika. Jurnal Aksioma 8(1), 76-86. 